\title{
BENTUK ATAP PADA KAWASAN PECINAN DESA BABAGAN DI KOTA WISATA LASEM
}

\author{
Adi Sasmito1, Mutiawati Mandaka², Ovariszar Bagus Affandi 3 \\ ${ }^{1}$ Universitas Pandanaran, Program Studi Arsitektur \\ adisas@unpand.ac.id \\ ${ }^{2}$ Universitas Pandanaran, Program Studi Arsitektur \\ mutia.mandaka@unpand.ac.id \\ 3 Universitas Pandanaran, Program Studi Arsitektur \\ ovariszar@unpand.ac.id
}

\begin{tabular}{|c|c|c|}
\hline \multicolumn{2}{|c|}{ Informasi artikel } & \multirow{2}{*}{$\begin{array}{l}\text { ABSTRAK } \\
\text { Desa wisata Batik Tulis Lasem adalah salah satu tujuan wisatawan di Jawa }\end{array}$} \\
\hline Sejarah & \multirow[b]{3}{*}{25 Maret 2021} & \\
\hline artikel: & & \multirow{10}{*}{$\begin{array}{l}\text { Tengah. Terdapat satu desa yang memiliki keunikan pada pemukimannya yaitu } \\
\text { desa Babagan yang dihuni mayoritas oleh keturunan Tionghoa. Paper ini } \\
\text { bertujuan untuk mengetahui apakah bentuk atap yang ada di pemukiman desa } \\
\text { Babagan serupa dengan bentuk atap yang ada dari daerah asal pendatang yang } \\
\text { diduga berasal dari Fujian dan Guangdong. Penelitian ini menggunakan metode } \\
\text { deskriptif kualitatif. Hasil penelitian berupa bentukan arsitektur atap rumah } \\
\text { tinggal China yang ada di Lasem merupakan bentuk atap yang serupa dengan } \\
\text { yang ada di provinsi Fujian China. }\end{array}$} \\
\hline Diterima & & \\
\hline Revisi & & \\
\hline Dipublikasikan & 30 Maret 2021 & \\
\hline \multirow{6}{*}{\multicolumn{2}{|c|}{$\begin{array}{l}\text { Kata kunci: } \\
\text { Bentuk atap rumah China } \\
\text { Fujian } \\
\text { Permukiman desa } \\
\text { Desa Babagan } \\
\text { Lasem }\end{array}$}} & \\
\hline & & \\
\hline & & \\
\hline & & \\
\hline & & \\
\hline & & \\
\hline \multirow{7}{*}{\multicolumn{2}{|c|}{$\begin{array}{l}\text { Key word: } \\
\text { The shape of the roof of a Chinese } \\
\text { house } \\
\text { Fujian } \\
\text { Village settlement } \\
\text { Babagan village } \\
\text { Lasem }\end{array}$}} & ABSTRACT \\
\hline & & Batik Tulis Lasem tourism village is one of the tourist destinations in Central Java. \\
\hline & & $\begin{array}{l}\text { There is one village that is unique in its settlement, namely Babagan Village which } \\
\text { is inhabited by Chinese descendants. This paper aims to see whether the roof shape }\end{array}$ \\
\hline & & in Babagan village is similar to the existing roof from the origin of immigrants who \\
\hline & & are thought to have come from Fujian and Guangdong. This study used descriptive \\
\hline & & qualitative method. The result of this research is the architectural form of the roof \\
\hline & & $\begin{array}{l}\text { of a Chinese residence in Lasem, which is similar to that of the Chinese province of } \\
\text { Fujian. }\end{array}$ \\
\hline
\end{tabular}

\section{PENDAHULUAN}

Lasem adalah salah satu kecamatan kota Rembang yang berada di Jawa Tengah, memiliki banyak potensi termasuk potensi pariwisata. Salah satu kerajinan tangan yang sangat terkenal adalah batik tulis Lasem. Kelebihan batik tulis ini dibandingkan dengan beberapa batik tulis yang juga terkenal di Jawa Tengah adalah warna merah darah atau getih pitik yang tidak ditemukan di tempat lain. Batik ini pada awalnya dibuat oleh etnis Tionghoa yang mulai menetap di Lasem. Orang-orang Tionghoa ini pertama kali mendarat di pantai Caruban, sebuah pelabuhan tua yang sudah musnah. Selain berdagang, mereka juga memproduksi batik tulis untuk menyambung hidup. Desa Babagan merupakan salah satu dari beberapa desa wisata batik tulis di Lasem. Terletak di perbatasan antara Kecamatan Rembang dengan Kecamatan Sluke dan Pancur. Luas wilayah Desa Babagan mencapai 195,9 Ha. Adapun batas-batas administrasi Desa Babagan adalah berbatasan dengan Desa Gedongmulyo pada bagian Utara, berbatasan dengan Desa Karasgede pada sisi Selatan, berbatasan dengan Desa Karangturi pada sisi Timur dan berbatasan dengan Desa Korokandang pada sisi Barat. Di dalam desa Babagan terdapat sebuah kawasan pecinan dimana warganya sebagian besar merupakan keturunan etnis Tionghoa.

Berdasarkan sejarah yaitu pada abad ke-13 ketika orang China pertama kali tiba dan menetap di Lasem, mereka mulai membangun permukiman permanen di dataran rendah bagian Timur sungai Lasem sekitar abad 15, dimana sebuah pelabuhan terletak sebagai pusat perdagangan (Pratiwo \& Nazir, 2010). Tidak ada keterangan pasti asal muasal darimana mereka berasal namun disebutkan oleh 
beberapa peneliti yaitu Borel, Salmon, Ong Eng Die, Wang Gong Wu serta yang lainnya bahwa Fujian dan Guangdong adalah asal dari etnis China yang berada di Nusantara.

Karakter fisik yang sangat menonjol pada kawasan Pecinan di Lasem antara lain struktur ruang kawasan yang membentuk pola permukiman berbentuk gurita atau bintang, pola permukiman yang membentuk blok bangunan, tipologi bangunan yang terdiri dari denah yang menggunakan prinsip keseimbangan (Yin-Yang) serta menerapkan prinsip simetri, bentuk atap bangunan berbentuk atap pelana dan pada ujungnya terdapat lengkungan kearah atas, pintu gerbang berbentuk gapura dan gerbang berbentuk rumah, struktur dan konstruksi khas yang menyangga atap pada kantilever yang biasa disebut Tou Kung, elemen dinding menggunakan dinding kayu pada dinding ruang altar, elemen pendukung seperti pintu dan jendela yang menggunakan bahan dasar kayu jati dan elemen ragam hias berupa gambar-gambar simbolisasi dari sifat tumbuhan maupun hewan (M. M. Sudarwani et al., 2019).

Menurut Rapoport (1969) bahwa tiga faktor pembentuk tatanan permukiman yaitu kelompok komunitas dengan socio culture yang dimiliki, kondisi alam sekitar dan bentuk lingkungan bangunan. Kawasan Pecinan yang berada di Babagan memiliki karakter yang khas yang bisa dilihat dari segi latar belakang sejarahnya, wujud fisik berupa artefak dan aktivitas yang berlangsung didalamnya. Penelitian-penelitian terdahulu lebih banyak fokus kepada simbolisasi rumah tinggal etnis China ( $M$. Sudarwani, 2012), bentuk dan makna atap China (Li \& Liu, 2017), perkembangan bangunan etnis Tionghoa (Handinoto, 2008), belum ada yang membahas terkait dengan keberadaan bentuk atap permukiman China secara mendetail. Berdasarkan latar belakang sejarahnya, terbentuknya permukiman ini diawali dari para pendatang etnis China yang diduga berasal dari negara asalnya di China yaitu di daerah Fujian. Ciri khas fisik yang paling menonjol adalah bentukan atap rumah pada permukiman di Fujian China. Sifat fungsional, pemodelan bentuk dan filosofi budaya intrinsik atap merupakan alasan mengapa atap dapat merepresentasikan citra arsitektur klasik Tiongkok (Li \& Liu, 2017). Penelitian ini bertujuan untuk mengetahui apakah bentuk atap yang ada di Pecinan Lasem khususnya di desa Babagan ini serupa dengan bentuk atap yang ada di pemukiman China di Fujian.

\section{METODOLOGI}

Penelitian ini mengunakan metode qualitative research, dengan menjelaskan kondisi yang ada pada eksisting dengan mencari korelasi, survey di lapangan dan melakukan studi pengembangan atau studi tindak lanjut terhadap masalah yang diteliti. Sesuai dengan karakteristiknya metode ini memiliki tujuan yaitu salah satunya adalah memperoleh pemahaman makna. Lokus penelitian adalah di kawasan Pecinan Lasem khususnya di Desa Babagan. Adapun referensi yang menjadi rujukan penelitian adalah Pecinan yang ada di China.

1. Beberapa tipe rumah vernakular di China, dapat dilihat pembagian lokasinya pada peta berikut: 


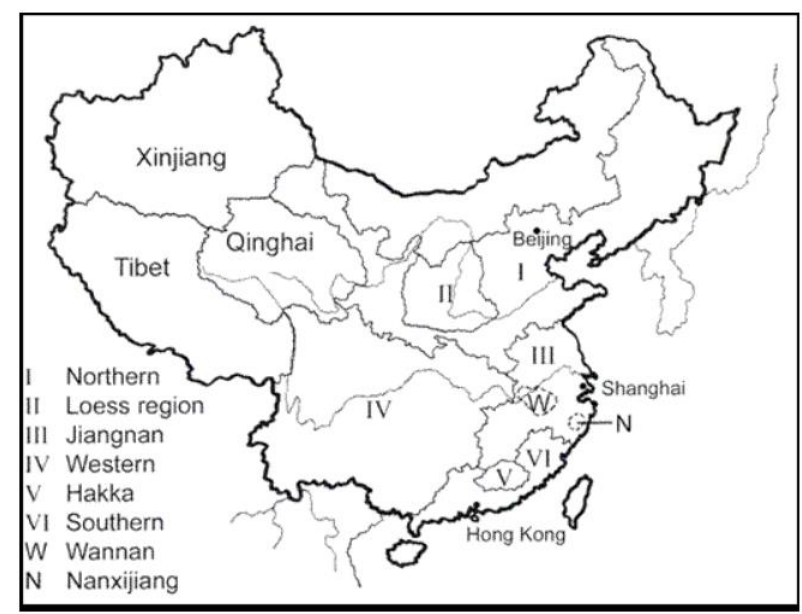

Gambar 1. Peta pembagian wilayah arsitektur Vernakular di China

Tipe arsitektur vernakular di China :

a. Northen China (Siheyuan) (I), Rumah Bata dengan ruang terbuka persegi;

b. Shanxi, Shaanxi, dan Provinsi Henan (II). Arsitektur Subterranean;

c. West and South West China (III), Arsitektur dengan konstruksi kayu dan bata;

d. Eastern China (IV), menggunakan konstruksi kayu;

e. Hakka (Fujian), Guangdong dan Jiangxi (V), arsitektur tanah liat dan kayu;

f. Southern China (VI), menggunakan batu bata, kayu dan bangunan batu.

Berikut tipologi rumah China, dapat dilihat pada tabel :

\begin{tabular}{|c|c|c|c|c|c|c|}
\hline $\begin{array}{l}\text { Northern } \\
\text { China }\end{array}$ & $\begin{array}{l}\text { Loess } \\
\text { Region }\end{array}$ & $\begin{array}{c}\text { Subterranea } \\
\text { n House }\end{array}$ & $\begin{array}{l}\text { Eastern } \\
\text { China }\end{array}$ & $\begin{array}{l}\text { Western } \\
\text { and South- } \\
\text { Western } \\
\text { China }\end{array}$ & $\begin{array}{l}\text { Hakka } \\
\text { Region } \\
\text { (Fujian) }\end{array}$ & $\begin{array}{c}\text { The Southern } \\
\text { Coast }\end{array}$ \\
\hline $\begin{array}{l}\text { - memiliki } \\
\text { halaman } \\
\text { tengah } \\
\text { siheyuan) } \\
\text { - adanya } \\
\text { hutong } \\
\text { - gerbang } \\
\text { berornam } \\
\text { en menuju } \\
\text { courtyard } \\
\text { (chuihuam } \\
\text { en) } \\
\text { - jumlah } \\
\text { courtyard } \\
\text { berdasark } \\
\text { an besar } \\
\text { rumah }\end{array}$ & $\begin{array}{l}\text {-cave } \\
\text { dwelling } \\
\text {-subterran } \\
\text { ean house } \\
\text {-terdapat } \\
\text { kang } \\
\text { - merupaka } \\
\text { n desa } \\
\text { yang } \\
\text { berasal } \\
\text { dari } \\
\text { bentukan } \\
\text { gua } \\
\text { terletak di } \\
\text { gansu dan } \\
\text { masing- } \\
\text { masing } \\
\text { rumah } \\
\text { terdapat } \\
\text { courtyard }\end{array}$ & $\begin{array}{l}\text { - frontage } \\
\text { rumah } \\
\text { memiliki } \\
\text { posisi } \\
\text { pada } \\
\text { sebuah } \\
\text { tebing } \\
\text { - terdapat } \\
\text { courtyard } \\
\text { tertutup } \\
\text { didalamny } \\
\text { a } \\
\text { - pintu } \\
\text { masuk } \\
\text { memiliki } \\
\text { lengkung } \\
\text { - terdapat } \\
\text { sirkulasi } \\
\text { udara dan } \\
\text { angin } \\
\text { dengan }\end{array}$ & $\begin{array}{l}\text { terbagi atas } \\
\text { dua } \\
\text { geografi : } \\
\text { - jiangsu } \\
\text { pada } \\
\text { dataran } \\
\text { yang } \\
\text { cukup } \\
\text { landai dan } \\
\text { zhejiang } \\
\text { pada } \\
\text { bagian } \\
\text { utara } \\
\text { - anhui } \\
\text { pada } \\
\text { sebelah } \\
\text { selatan } \\
\text { dan } \\
\text { zhejiang } \\
\text { yaitu } \\
\text { daerah } \\
\text { berbukit }\end{array}$ & $\begin{array}{l}\text { - brick } \\
\text { house } \\
\text { - bentuk } \\
\text { atap } \\
\text { berunda } \\
\text { k atau } \\
\text { bertingk } \\
\text { at- } \\
\text { tingkat } \\
\text { - small } \\
\text { courtyar } \\
\text { d }\end{array}$ & $\begin{array}{l}\text { - besar, } \\
\text { berbentu } \\
\text { k persegi } \\
\text { dan } \\
\text { lingkaran } \\
\text { - terbuat } \\
\text { dari bata } \\
\text { (brick) } \\
\text { - adanya } \\
\text { enclose } \\
\text { structure } \\
\text { (weizi) }\end{array}$ & $\begin{array}{l}\text { - courtyard } \\
\text { house } \\
\text { - granite } \\
\text { block dan } \\
\text { bata merah } \\
\text { dan kayu } \\
\text { merupakan } \\
\text { material } \\
\text { bangunann } \\
\text { ya } \\
\text { - dekorasi } \\
\text { bagian atap } \\
\text { terbuat dari } \\
\text { material } \\
\text { kayu dan } \\
\text { terdapat } \\
\text { teknologi } \\
\text { rumah } \\
\text { bawah } \\
\text { tanah } \\
\text { (yaodong) }\end{array}$ \\
\hline
\end{tabular}




\begin{tabular}{lll}
\hline bukaan di & $\bullet$ berada di & $\bullet$ clay brick \\
bagian & sepanjang & \\
rumah & sungai & mud brick \\
& yangtze & $\bullet$ adobe brick \\
& $\bullet$ courtyard & $\bullet$ kayu dan \\
& brick gate & genteng \\
& $\bullet$ suzhouw & (konstruksi \\
& houses & atap) \\
& & - jian dipakai \\
& & sebagai \\
& modul atau \\
& & standar \\
dimensi
\end{tabular}

\section{Bentukan Atap rumah China}

Menurut Khudori (2019), atap rumah China memiliki 3 fitur khas yang dimiliki, yaitu:

a. Sistem penyambungan kayu

Pada bangunan dengan arsitektur China, material kayu digunakan dengan posisi balok saling silang dan menjadikannya fit satu dengan yang lainnya, teknik tersebut menjadikan bangunan terkesan kuat, kokoh, dan juga menarik dipandang.

b. Lengkungan yang anggun pada bentuk atap

Pada zaman Dinasti Han, bentuk lengkung ini sudah ada (206 - 220 SM)

c. Bentuk ubin yang bulat

Berbentuk busur atau setengah lingkaran yang kemudian ubin tersebut disusun dan diletakkan membentang.

Atap pada bangunan China memiliki ciri tingkat kemiringan yang cukup tinggi, dengan susunan bentuk tunggal atau bertumpuk. Selain fitur khas yang dimiliki pada atap rumah China, terdapat hal penting lainnya yang terdapat pada arsitektur China terutama bagian atap, yaitu :

a. Fungsi atap bangunan China

- Drainase

Dengan kemiringan yang cukup tinggi dan melengkung berfungsi untuk mengurangi beban pada atap.

- Perlindungan

Penggunaan struktur kayu atau batu agar tidak terkena erosi akibat air hujan dan kondisi berbagai cuaca yang terjadi.

- Simbol hirarki

Penggunaan bentuk atap juga menyimbolkan status dari pemilik bangunan.

b. Bentuk-bentuk struktur atap China

Terdapat 5 bentuk atap khas rumah China, yaitu :

- Atap pelana, atap jenis ini dibagi menjadi 2 : Hsuan Shan dan Ngang Shan. Hsuan Shan adalah atap pelana yang ditopang oleh dinding kayu atau biasa sedangkan Ngang Shan adalah atap pelana yang ditopang oleh dinding tembok.

- Kombinasi atap jurai dengan atap pelana (Hsuan Shan).

- Bentuk atap seperti piramida (Tsuan Tsien).

- Bentuk atap dengan jurai (Wu Tien). 


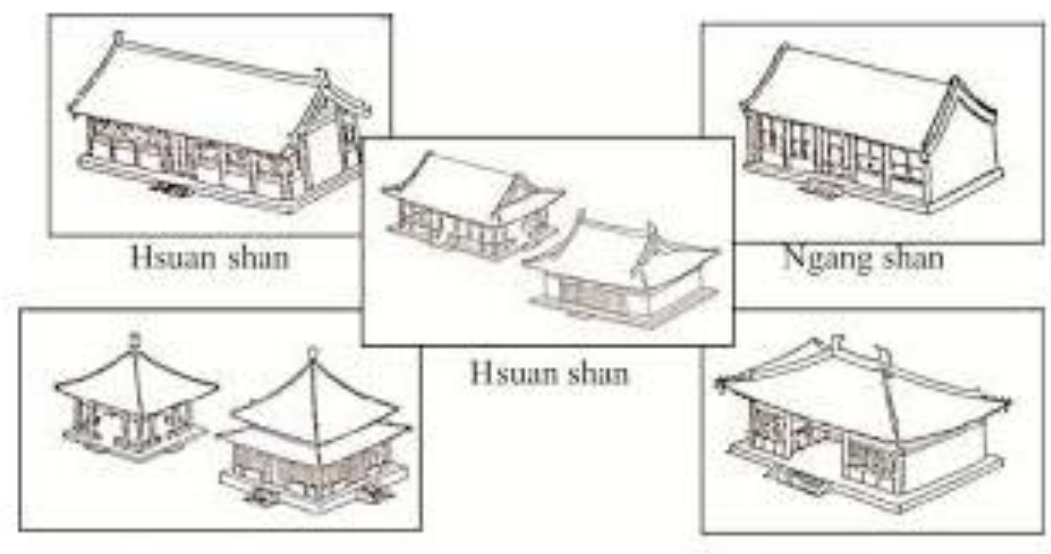

Tsuan tsien

Wu Tien

Gambar 2. Tipe atap China

c. Dekorasi dan bentuk atap bangunan khas China

Selain memiliki sudut kemiringan yang cukup tinggi dan berbentuk melengkung, atap pada bangunan China juga terdapat ornamen yang menghiasinya dan warna pada atap bangunan China memiliki makna tersendiri. Menurut (Khol, 1984), dekorasi atap (bubungan) pada bangunan China memiliki 5 jenis, yaitu:

Tabel 2. Tipe bubungan atap China

\begin{tabular}{clcc}
\hline No Tipe Bubungan & \\
\hline $1 \quad$ lancip pada ujungnya (end of straw) & geometri (geometric) \\
\hline $2 \quad$ awan bergulung (rolling wave) & awan berombak (curling wave)
\end{tabular}


5 awan meliuk atau ujung meliuk (curling end)

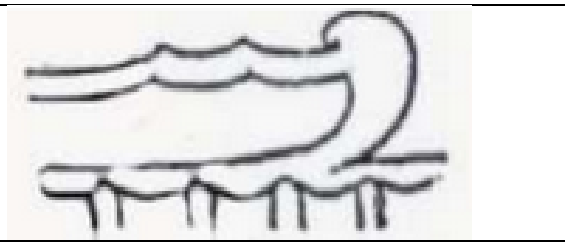

d. Filosofi struktur atap khas China Indonesia

Dalam arsitektur China terdapat hal yang mempengaruhi terutama filosofi dari kepercayaan Konfusianisme, Taoisme, dan Budhisme. Berdasarkan tradisi China, atap adalah perlambangan simbol surgawi karena fungsinya sebagai pelindung bagi yang berada dibawahnya.

3. Bentukan atap pada pemukiman rumah China :

a. Northern China

Siheyuan merupakan penumpukan ruang utama, ruang sisi timur dan barat, serta ruang belakang. Halamannya dikelilingi oleh empat ruangan di tengah, itulah mengapa nama Siheyuan berasal. Siheyuan adalah simbol nilai keluarga dan kehidupan tradisional Tiongkok. Bentukan atap yang banyak digunakan di permukiman China bagian Utara ini adalah Ngang Shan yaitu model atap pelana dengan bertumpu pada dinding.

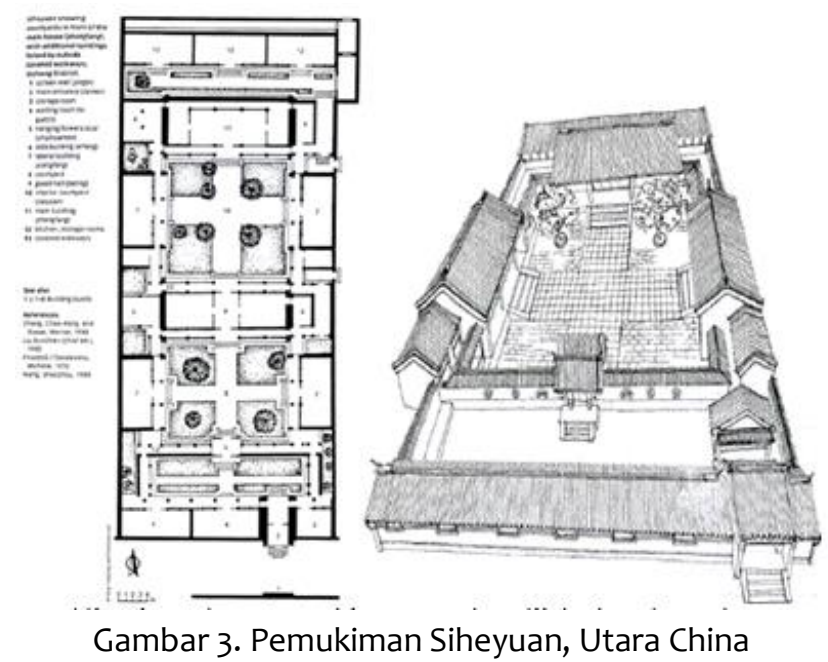

b. Loes Region

Di dataran tinggi Loess di utara Cina, permukiman gua disebut YaoDong didistribusikan secara luas. Permukiman ini menyesuaikan diri dengan kondisi alam yang parah tersebut seperti geografi dan iklim didaerah ini (Zhou et al., 2002). Berdasarkan lokasi dan bentuk alamnya maka atap pada bangunan permukiman ini menyatu dengan bentukan gua sehingga bentukan atapnya tidak menonjol. Bentukan permukiman ini sangat memanfaatkan bentukan alam sebagai tempat bermukim orang China di wilayah ini. 


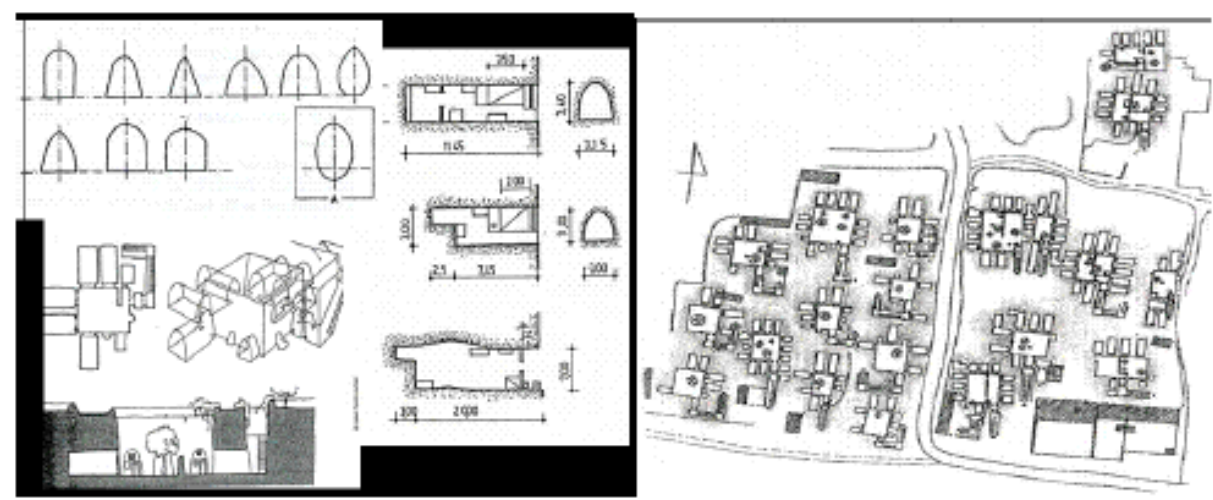

Gambar 4. Pemukiman YaoDong, Utara China

\section{c. Subterranean House}

Tipe rumah yang ada di subterranean ini memiliki ciri-ciri berada di salah satu sisi tebing. Memiliki courtyard tertutup dengan bentukan bagian atapnya menempel dengan tebing. Sedangkan bentukan entryway pada rumahnya cenderung memakai vault (lengkung) sehingga pada rumah subterranean house ini bentukan atap tidak menjadi ciri khas utama seperti bentukan atap di permukiman China yang lain.

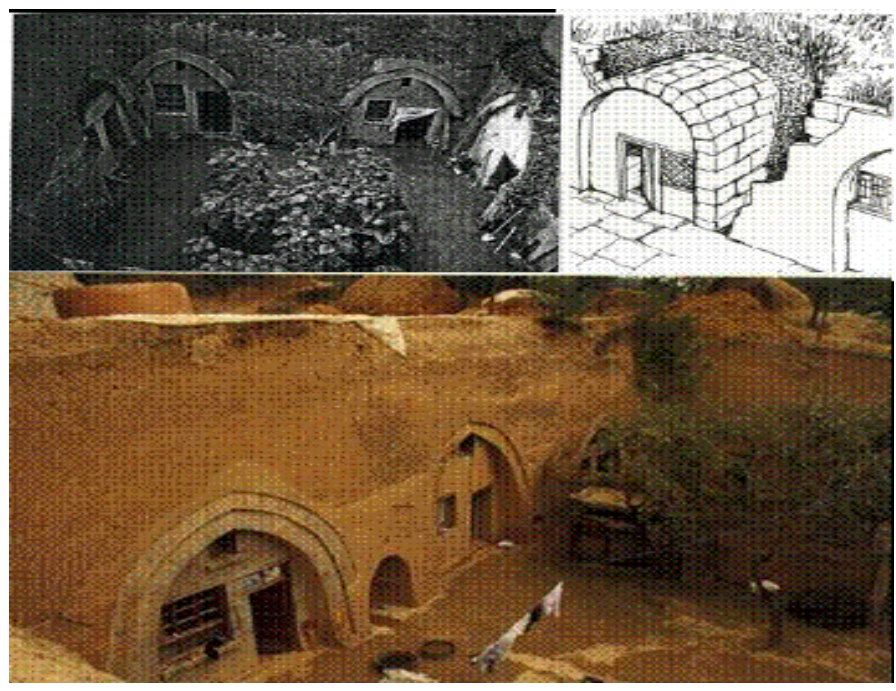

Gambar 5. Subterranean house

\section{d. Eastern China}

Atap tradisional dibangun dengan meletakkan kayu atap yang semakin panjang yang dipasang di atas satu sama lain dengan purlins di ujungnya. Seluruh atap bertumpu pada serangkaian kayu ortogonal yang membentang di antara pilar-pilar yang berjarak sama. Kayunya disambung, bukan dipaku bersama. Pengaturan kantilever digunakan untuk mendukung atap yang menggantung. Seluruh atap ditutupi dengan lapisan ubin terakota cekung dan cembung, meskipun di daerah pedesaan jerami digunakan. Langit-langit di bawahnya bisa datar atau berkubah. Dalam desain atap terdapat pembagian kunci antara Cina utara dan selatan. Di utara, atap harus mengatasi beban salju yang berat sedangkan di selatan lebih banyak naungan yang dibutuhkan sehingga atap selatan lebih melengkung dan rumit. Atap ini mungkin memiliki atap yang sangat melengkung sehingga sudutnya mengarah ke atas (atap terbang) dan mencapai ketinggian yang sama dengan bagian atas atap. Kemungkinan besar atap di Burma dan Thailand memengaruhi gaya ini. 


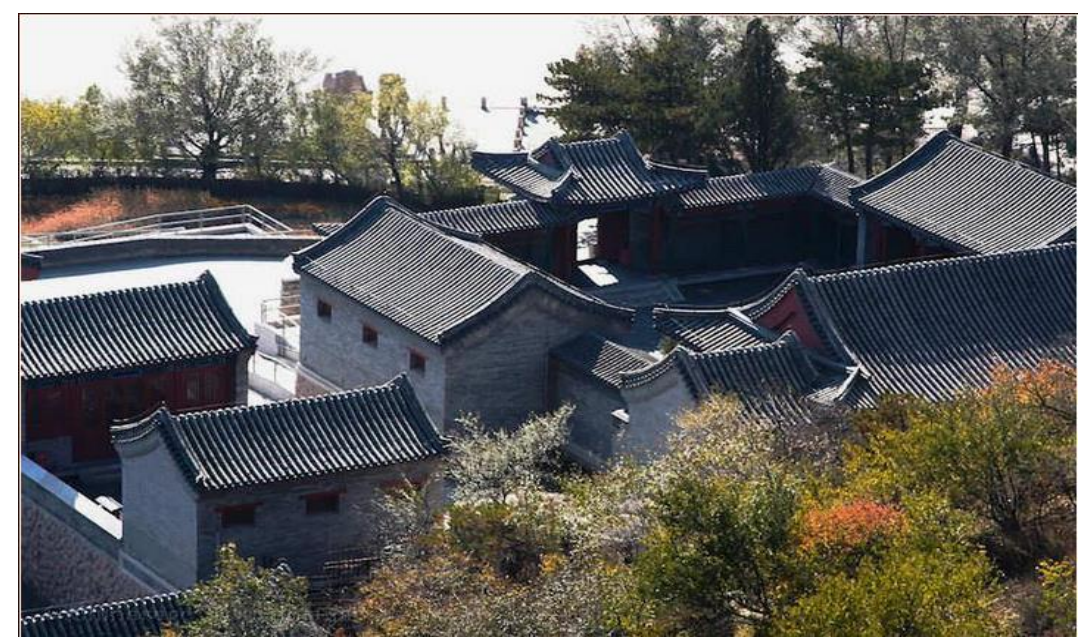

Gambar 6. Atap Permukiman di Eastern China (Chinasage, 2020)

e. Western and South-Western China

Pada daerah China bagian Barat ataupun Barat Daya, permukiman tradisional yang ada yaitu di daerah Yunan tepatnya di Nuodeng Bai village dengan ciri khas brick house yaitu material dinding rumahnya menggunakan batu bata merah. Batanya sendiri dibuat menggunakan material lokal yang ada di Yunan. Dan permukiman ini terletak di perbukitan sehingga courtyard yang ada pada permukiman ini relatif kecil. Untuk bentukan atap, pada permukiman Nuodeng Bai village ini sendiri menggunakan atap model Hsuan Shan (pelana).

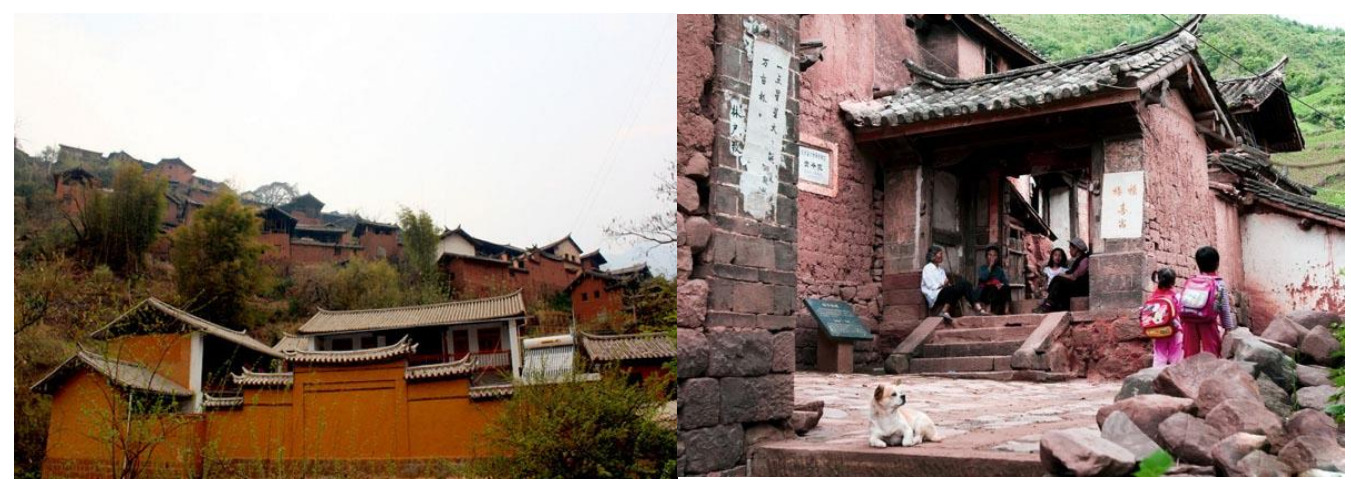

Gambar 7. Gambar Nuodeng Bai Village di Yunan China bagian Barat Daya

f. Haka Region

Fujian Tulou memungkinkan pertahanan dan kemakmuran klan dan otonomi sempurna mereka sambil mereproduksi pola komunal tradisional keluarga Tionghoa di sebuah bangunan berkinerja tinggi yang terintegrasi dengan pegunungan Fujian. Semua karakteristik ini menjadikan mereka bangunan ikonik, mencerminkan citra marga yang mendiami. Model tersebut berkembang dan menyebar di wilayah Fujian tetapi juga di sekitar Tulou asli. Kelompok Tulou ini adalah kelompok yang terdiri dari beberapa bangunan yang sering mencampurkan bentuk. Untuk bentuk atapnya sendiri, menyesuaikan dari bentuk bangunan yaitu melingkar. Pada inner courtyard terdapat bangunan yang atapnya menggunakan model Ngang Shan yaitu atap pelana dengan dinding tembok. 

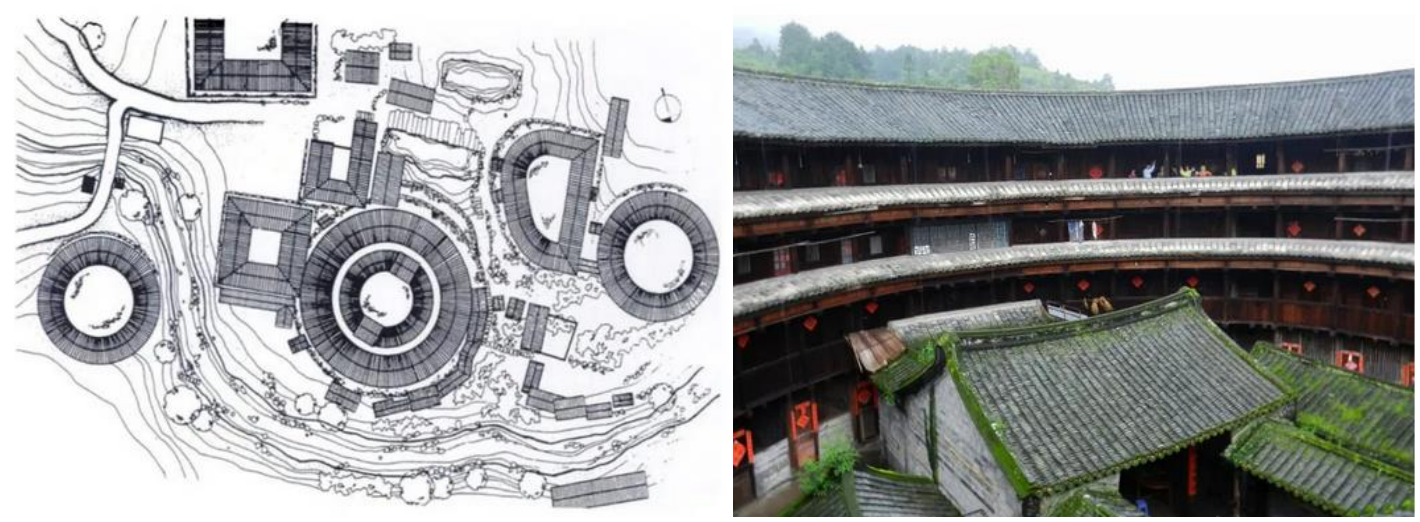

Gambar 8. Pemukiman Tulou, Fujian (Atlas, 2020)

g. Southern Coast

Pada daerah Selatan provinsi Fujian, ada beberapa permukiman tradisional China. Yaitu antara lain permukiman kuno di Quanzhou, permukiman kuno di Xiamen Haicang, dan rumah-rumah kuno di desa Zhangzhou Longhai Dai Wei. Ciri khas yang agak menonjol pada permukiman disini adalah penggunaan warna merah pada bangunan, terutama di permukiman Quangzhou. Warna menyimbolkan keberuntungan dan kebahagiaan untuk masyarakat China. Penggunaan atap di ketiga desa ini hampir sama, yaitu menggunakan atap model Hsuan Shan yang berupa atap pelana.

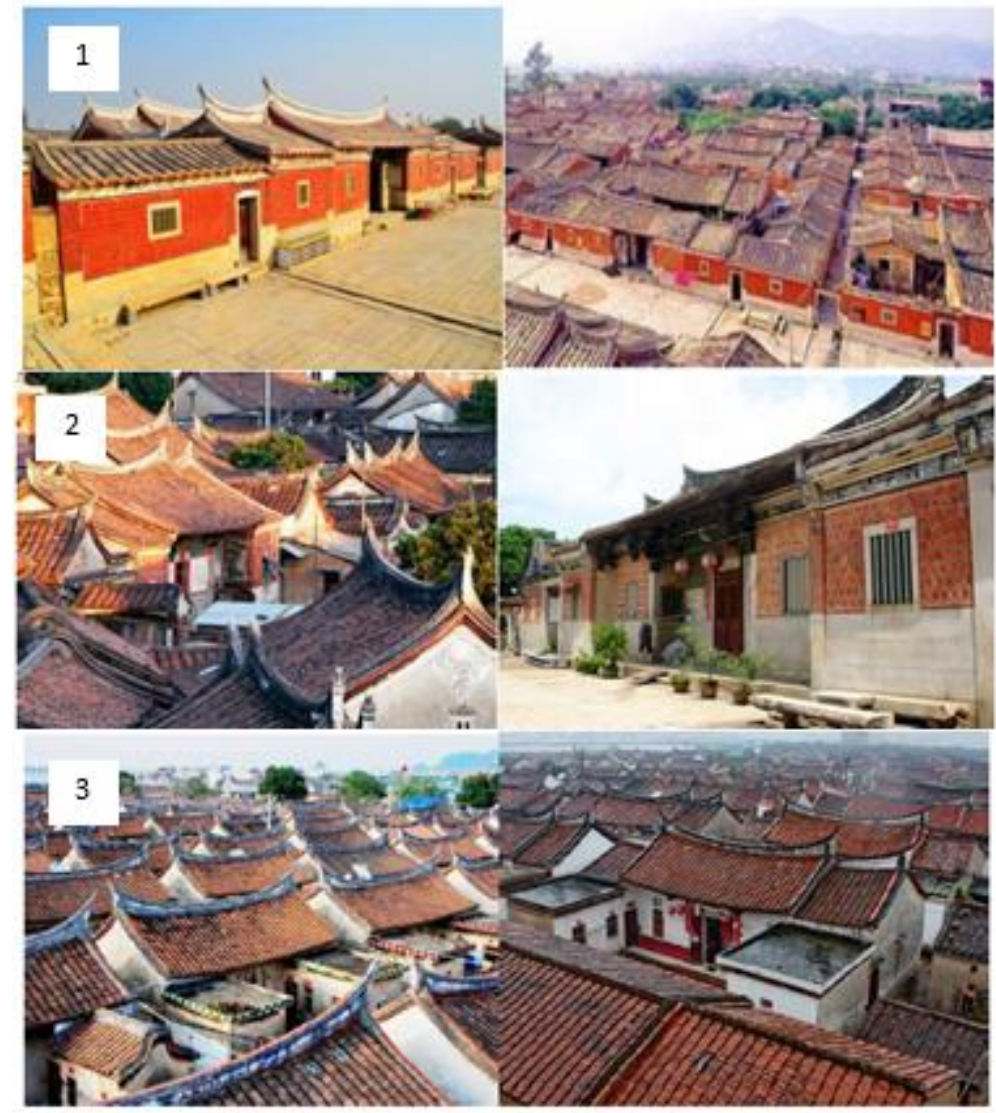

Gambar 9. (1) Permukiman kuno Quanzhou (2) Permukiman kuno Xiamen Haicang (3)Permukiman tradisional Zhangzhou Longhai Dai Wei (Jin, 2016) 


\section{HASIL DAN PEMBAHASAN}

Berikut pembahasan terkait bentuk atap China yang ada pada permukiman di desa wisata Batik Tulis Lasem, khususnya di desa Babagan :

Tabel 2. Ciri-ciri bentukan atap pada bangunan China di Desa Babagan

\begin{tabular}{|c|c|c|c|c|}
\hline No & Ciri-ciri & Tipe/Jenis & Gambar & $\begin{array}{c}\text { Atap bangunan } \\
\text { Pecinan di } \\
\text { Babagan }\end{array}$ \\
\hline \multirow{5}{*}{\multicolumn{2}{|c|}{1 bentuk atap }} & $\begin{array}{l}\text { atap berbentuk } \\
\text { jurai (wu tien) }\end{array}$ & & $\begin{array}{l}\text { tidak ada rumah } \\
\text { yang } \\
\text { menggunakan jenis } \\
\text { atap ini di } \\
\text { permukiman } \\
\text { pecinan babagan }\end{array}$ \\
\hline & & $\begin{array}{l}\text { atap pelana } \\
\text { model hsuan shan }\end{array}$ & & $\begin{array}{l}\text { ada beberapa } \\
\text { rumah yang } \\
\text { menggunakan jenis } \\
\text { atap ini di } \\
\text { permukiman } \\
\text { pecinan di babagan }\end{array}$ \\
\hline & & $\begin{array}{l}\text { atap pelana } \\
\text { model ngang shan }\end{array}$ & & $\begin{array}{l}\text { sebagian besar } \\
\text { bentuk atap } \\
\text { permukiman } \\
\text { pecinan di babagan } \\
\text { berbentuk atap } \\
\text { pelana dengan } \\
\text { dinding tembok } \\
\text { sebagai } \\
\text { penyangganya }\end{array}$ \\
\hline & & $\begin{array}{l}\text { kombinasi atap } \\
\text { jurai dengan atap } \\
\text { pelana (hsuan } \\
\text { shan) }\end{array}$ & & $\begin{array}{l}\text { tidak ada rumah } \\
\text { yang } \\
\text { menggunakan jenis } \\
\text { atap ini di } \\
\text { permukiman } \\
\text { pecinan babagan }\end{array}$ \\
\hline & & $\begin{array}{l}\text { atap seperti } \\
\text { piramida (tsuan } \\
\text { tsien) }\end{array}$ & & $\begin{array}{l}\text { tidak ada rumah } \\
\text { yang } \\
\text { menggunakan jenis } \\
\text { atap ini di } \\
\text { permukiman } \\
\text { pecinan babagan }\end{array}$ \\
\hline 2 & bubungan & tipe ujung lancip & & $\begin{array}{l}\text { bubungan pada } \\
\text { bangunan } \\
\text { permukiman china } \\
\text { di babagan ada } \\
\text { yang berbentuk } \\
\text { ujung lancip }\end{array}$ \\
\hline
\end{tabular}




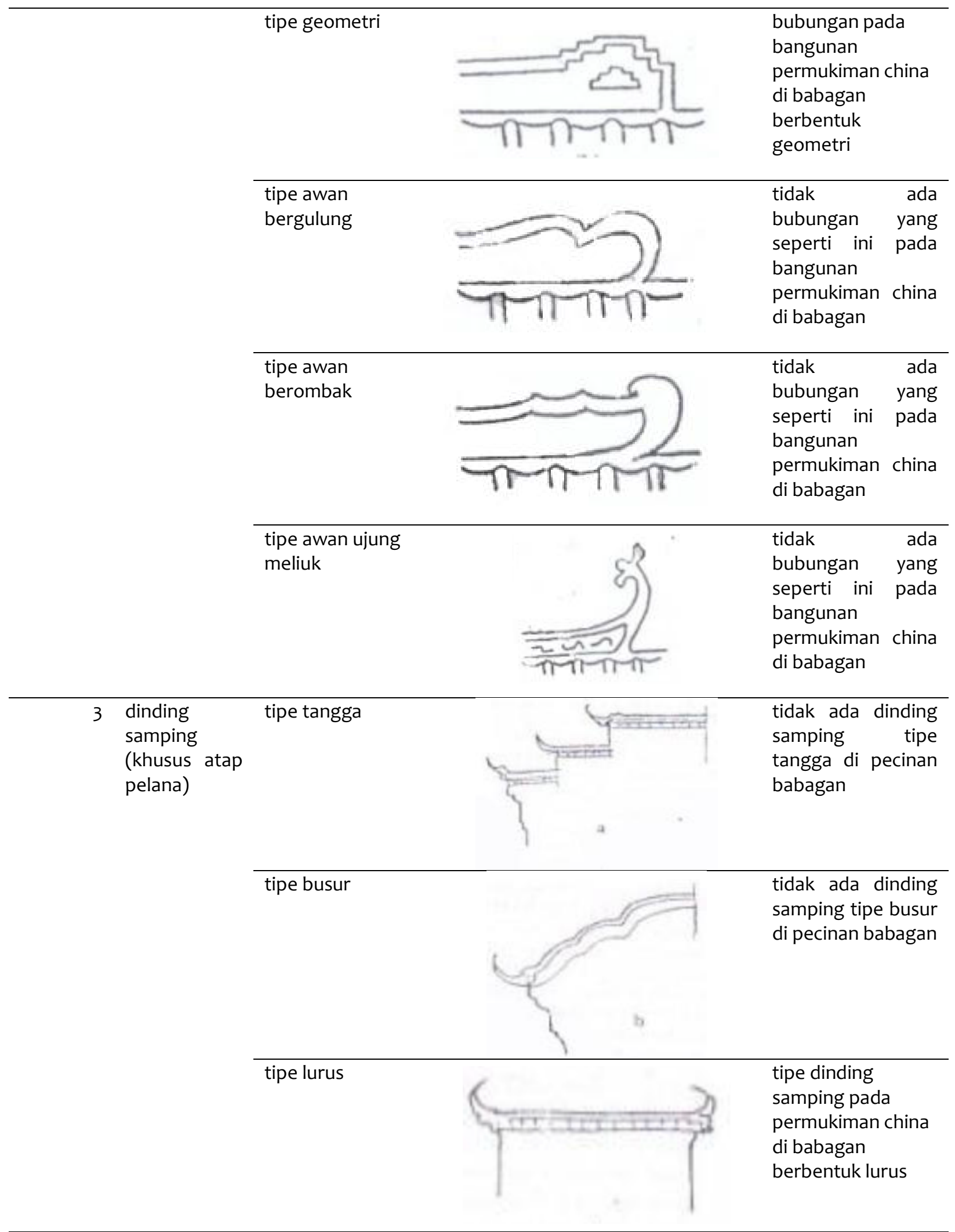




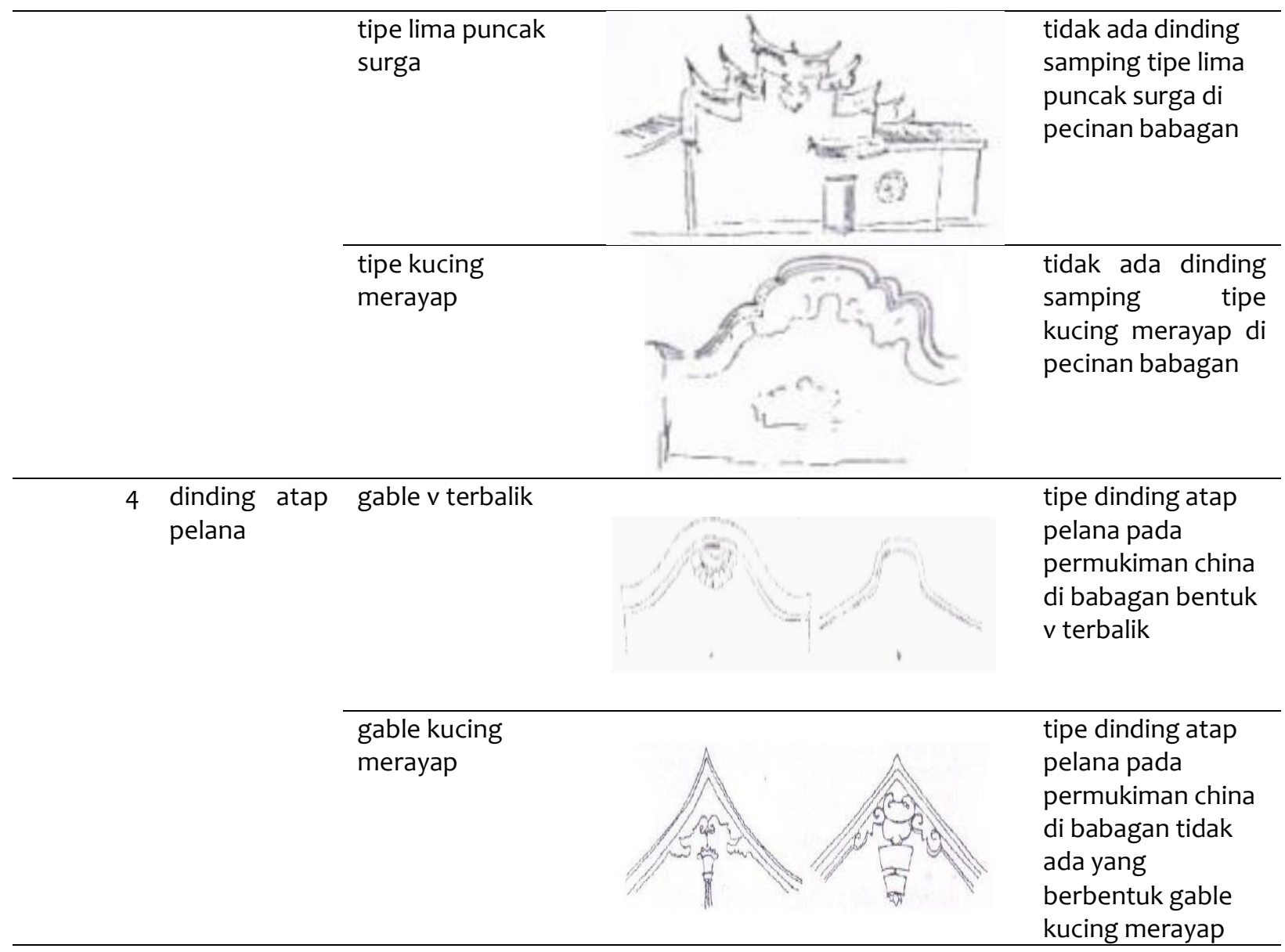

Setelah mengetahui bentukan atap China yang ada di desa Babagan, selanjutnya perlu menganalisa bentukan atap yang ada di negara asalnya sebagai berikut :

Tabel 3. Bentuk atap yang menyerupai permukiman arsitektur vernakular di China

\begin{tabular}{|c|c|c|c|c|c|c|c|c|}
\hline No & $\begin{array}{c}\text { Ciri atap pada } \\
\text { permukiman China } \\
\text { Babagan-Lasem }\end{array}$ & $\begin{array}{l}\text { Northen } \\
\text { China }\end{array}$ & $\begin{array}{c}\text { Loess } \\
\text { Region }\end{array}$ & $\begin{array}{c}\text { Subterra } \\
\text { nean } \\
\text { House }\end{array}$ & $\begin{array}{c}\text { Easter } \\
\text { n China }\end{array}$ & $\begin{array}{l}\text { Western } \\
\text { and } \\
\text { South- } \\
\text { western } \\
\text { China }\end{array}$ & $\begin{array}{l}\text { Hakka } \\
\text { Region }\end{array}$ & $\begin{array}{l}\text { The } \\
\text { Souther } \\
\text { n Coast }\end{array}$ \\
\hline 1 & $\begin{array}{l}\text { atap pelana } \\
\text { dinding } \\
\text { (ngang shan) }\end{array}$ & $\begin{array}{l}\text { bentuk } \\
\text { atap } \\
\text { pada } \\
\text { permuki } \\
\text { man } \\
\text { china di } \\
\text { babagan } \\
\text { serupa } \\
\text { dengan } \\
\text { yang ada } \\
\text { di } \\
\text { permuki } \\
\text { man } \\
\text { china } \\
\text { utara }\end{array}$ & $\begin{array}{l}\text { bentuk } \\
\text { atap } \\
\text { pada } \\
\text { permuki } \\
\text { man } \\
\text { china di } \\
\text { babagan } \\
\text { tidak } \\
\text { serupa } \\
\text { dengan } \\
\text { yang ada } \\
\text { di } \\
\text { permuki } \\
\text { man }\end{array}$ & $\begin{array}{l}\text { bentuk } \\
\text { atap } \\
\text { pada } \\
\text { permuki } \\
\text { man } \\
\text { china di } \\
\text { babagan } \\
\text { tidak } \\
\text { serupa } \\
\text { dengan } \\
\text { yang ada } \\
\text { di } \\
\text { permuki } \\
\text { man } \\
\text { dibawah }\end{array}$ & $\begin{array}{l}\text { bentuk } \\
\text { atap } \\
\text { pada } \\
\text { permu } \\
\text { kiman } \\
\text { china } \\
\text { di } \\
\text { babaga } \\
\text { n } \\
\text { serupa } \\
\text { denga } \\
\text { n yang } \\
\text { ada di } \\
\text { permu } \\
\text { kiman }\end{array}$ & $\begin{array}{l}\text { bentuk } \\
\text { atap } \\
\text { pada } \\
\text { permuki } \\
\text { man } \\
\text { china di } \\
\text { babagan } \\
\text { tidak } \\
\text { serupa } \\
\text { dengan } \\
\text { yang ada } \\
\text { di } \\
\text { permuki } \\
\text { man } \\
\text { barat }\end{array}$ & $\begin{array}{l}\text { bentuk } \\
\text { atap } \\
\text { pada } \\
\text { permu } \\
\text { kiman } \\
\text { china } \\
\text { di } \\
\text { babaga } \\
\text { n } \\
\text { serupa } \\
\text { denga } \\
\text { n yang } \\
\text { ada di } \\
\text { permu } \\
\text { kiman }\end{array}$ & $\begin{array}{l}\text { bentuk } \\
\text { atap } \\
\text { pada } \\
\text { permuk } \\
\text { iman } \\
\text { china di } \\
\text { babaga } \\
\text { n } \\
\text { serupa } \\
\text { dengan } \\
\text { yang } \\
\text { ada di } \\
\text { permuk } \\
\text { iman } \\
\text { pantai }\end{array}$ \\
\hline
\end{tabular}




\begin{tabular}{|c|c|c|c|c|c|c|c|c|}
\hline & & & $\begin{array}{l}\text { loess, } \\
\text { china }\end{array}$ & $\begin{array}{l}\text { tanah, } \\
\text { china }\end{array}$ & $\begin{array}{l}\text { china } \\
\text { timur }\end{array}$ & $\begin{array}{l}\text { dan } \\
\text { barat } \\
\text { daya, } \\
\text { china }\end{array}$ & $\begin{array}{l}\text { hakka, } \\
\text { china }\end{array}$ & $\begin{array}{l}\text { selatan } \\
\text { china }\end{array}$ \\
\hline \multirow[t]{2}{*}{2} & tipe geometri & $\begin{array}{l}\text { bentuk } \\
\text { bubunga } \\
\text { n pada } \\
\text { permuki } \\
\text { man } \\
\text { china di } \\
\text { babagan } \\
\text { serupa } \\
\text { dengan } \\
\text { yang ada } \\
\text { di } \\
\text { permuki } \\
\text { man } \\
\text { china } \\
\text { utara }\end{array}$ & $\begin{array}{l}\text { bentuk } \\
\text { bubunga } \\
\text { n pada } \\
\text { permuki } \\
\text { man } \\
\text { china di } \\
\text { babagan } \\
\text { tidak } \\
\underline{\text { serupa }} \\
\text { dengan } \\
\text { yang ada } \\
\text { di } \\
\text { permuki } \\
\text { man } \\
\text { loess, } \\
\text { china }\end{array}$ & $\begin{array}{l}\text { bentuk } \\
\text { bubunga } \\
\text { n pada } \\
\text { permuki } \\
\text { man } \\
\text { china di } \\
\text { babagan } \\
\text { tidak } \\
\text { serupa } \\
\text { dengan } \\
\text { yang ada } \\
\text { di } \\
\text { permuki } \\
\text { man } \\
\text { dibawah } \\
\text { tanah, } \\
\text { china }\end{array}$ & $\begin{array}{l}\text { bentuk } \\
\text { bubun } \\
\text { gan } \\
\text { pada } \\
\text { permu } \\
\text { kiman } \\
\text { china } \\
\text { di } \\
\text { babaga } \\
\mathrm{n} \\
\text { serupa } \\
\text { denga } \\
\mathrm{n} \text { yang } \\
\text { ada di } \\
\text { permu } \\
\text { kiman } \\
\text { china } \\
\text { timur }\end{array}$ & $\begin{array}{l}\text { bentuk } \\
\text { bubunga } \\
\text { n pada } \\
\text { permuki } \\
\text { man } \\
\text { china di } \\
\text { babagan } \\
\text { tidak } \\
\text { serupa } \\
\text { dengan } \\
\text { yang ada } \\
\text { di } \\
\text { permuki } \\
\text { man } \\
\text { barat } \\
\text { dan } \\
\text { barat } \\
\text { daya, } \\
\text { china }\end{array}$ & $\begin{array}{l}\text { bentuk } \\
\text { bubun } \\
\text { gan } \\
\text { pada } \\
\text { permu } \\
\text { kiman } \\
\text { china } \\
\text { di } \\
\text { babaga } \\
\text { n } \\
\text { serupa } \\
\text { denga } \\
\text { n yang } \\
\text { ada di } \\
\text { permu } \\
\text { kiman } \\
\text { hakka, } \\
\text { china }\end{array}$ & - \\
\hline & tipe ujung lancip & - & - & - & - & $\begin{array}{l}\text { bentuk } \\
\text { bubunga } \\
\text { n pada } \\
\text { permuki } \\
\text { man } \\
\text { china di } \\
\text { babagan } \\
\text { serupa } \\
\text { dengan } \\
\text { yang ada } \\
\text { di } \\
\text { permuki } \\
\text { man } \\
\text { barat } \\
\text { dan } \\
\text { barat } \\
\text { daya } \\
\text { china }\end{array}$ & - & $\begin{array}{l}\text { bentuk } \\
\text { bubung } \\
\text { an pada } \\
\text { permuk } \\
\text { iman } \\
\text { china di } \\
\text { babaga } \\
\text { n } \\
\text { serupa } \\
\text { dengan } \\
\text { yang } \\
\text { ada di } \\
\text { permuk } \\
\text { iman } \\
\text { pantai } \\
\text { selatan } \\
\text { china }\end{array}$ \\
\hline 3 & dinding samping & $\begin{array}{l}\text { bentuk } \\
\text { dinding } \\
\text { samping } \\
\text { pada } \\
\text { permuki } \\
\text { man } \\
\text { china di } \\
\text { babagan } \\
\text { serupa } \\
\text { dengan } \\
\text { yang ada } \\
\text { di } \\
\text { permuki } \\
\text { man }\end{array}$ & $\begin{array}{l}\text { bentuk } \\
\text { dinding } \\
\text { samping } \\
\text { pada } \\
\text { permuki } \\
\text { man } \\
\text { china di } \\
\text { babagan } \\
\text { tidak } \\
\text { serupa } \\
\text { dengan } \\
\text { yang ada } \\
\text { di } \\
\text { permuki }\end{array}$ & $\begin{array}{l}\text { bentuk } \\
\text { dinding } \\
\text { samping } \\
\text { pada } \\
\text { permuki } \\
\text { man } \\
\text { china di } \\
\text { babagan } \\
\text { tidak } \\
\text { serupa } \\
\text { dengan } \\
\text { yang ada } \\
\text { di } \\
\text { permuki }\end{array}$ & $\begin{array}{l}\text { bentuk } \\
\text { dinding } \\
\text { sampin } \\
\text { g pada } \\
\text { permu } \\
\text { kiman } \\
\text { china } \\
\text { di } \\
\text { babaga } \\
\text { n } \\
\text { serupa } \\
\text { denga } \\
\text { n yang } \\
\text { ada di }\end{array}$ & $\begin{array}{l}\text { bentuk } \\
\text { dinding } \\
\text { samping } \\
\text { pada } \\
\text { permuki } \\
\text { man } \\
\text { china di } \\
\text { babagan } \\
\text { tidak } \\
\text { serupa } \\
\text { dengan } \\
\text { yang ada } \\
\text { di } \\
\text { permuki }\end{array}$ & $\begin{array}{l}\text { bentuk } \\
\text { dinding } \\
\text { sampin } \\
\text { g pada } \\
\text { permu } \\
\text { kiman } \\
\text { china } \\
\text { di } \\
\text { babaga } \\
\text { n } \\
\text { serupa } \\
\text { denga } \\
\mathrm{n} \text { yang } \\
\text { ada di }\end{array}$ & $\begin{array}{l}\text { bentuk } \\
\text { dinding } \\
\text { sampin } \\
\text { g pada } \\
\text { permuk } \\
\text { iman } \\
\text { china di } \\
\text { babaga } \\
\mathrm{n} \\
\text { serupa } \\
\text { dengan } \\
\text { yang } \\
\text { ada di } \\
\text { permuk }\end{array}$ \\
\hline
\end{tabular}




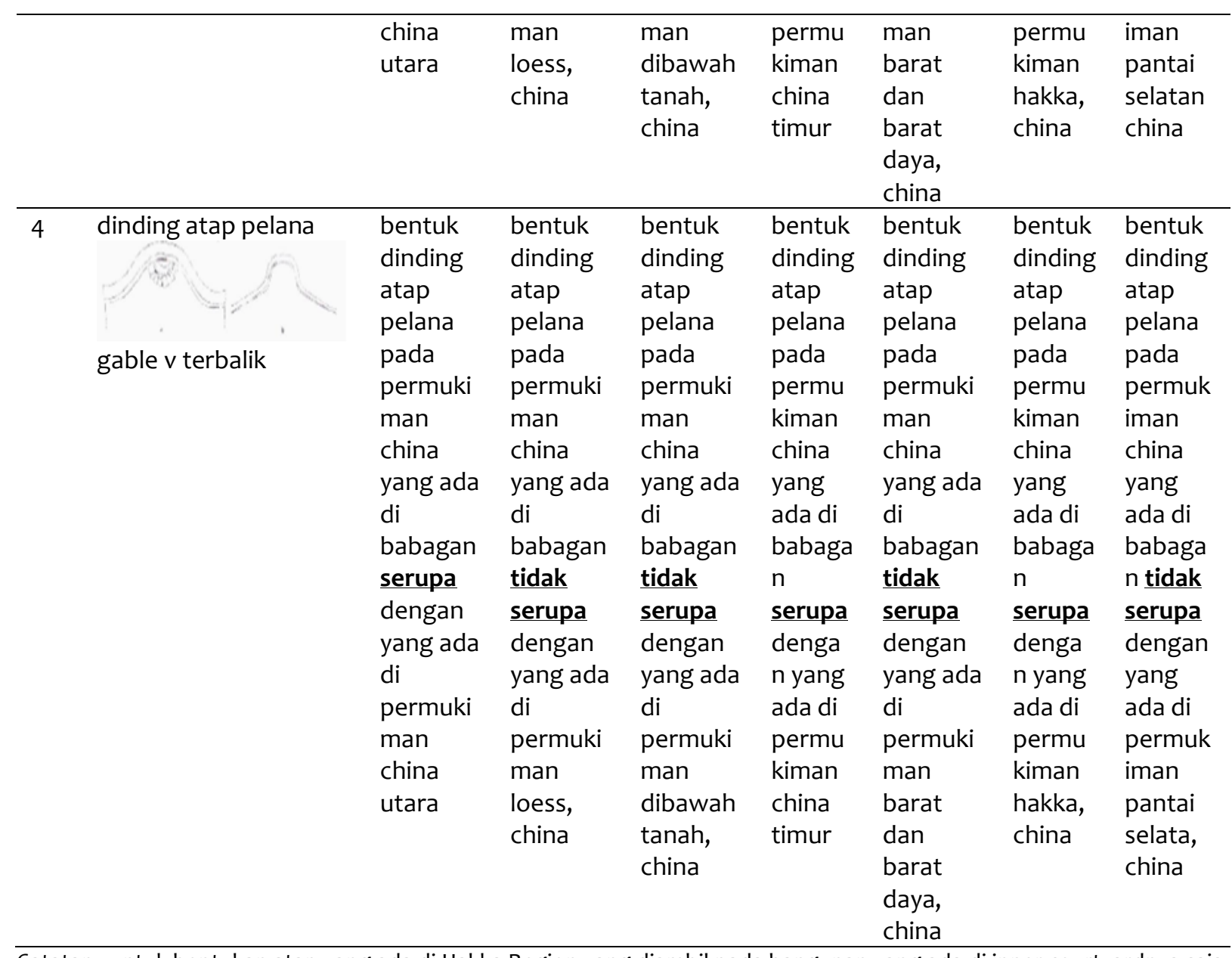

Catatan : untuk bentukan atap yang ada di Hakka Region yang diambil pada bangunan yang ada di inner courtyardnya saja.

\section{PENUTUP}

\section{Simpulan}

Setelah melakukan analisa terhadap bentukan-bentukan atap pada permukiman vernakular yang ada di China, dan meninjau bentukan atap yang ada di desa Babagan Lasem maka dapat ditarik kesimpulan bahwa bentukan atap yang ada di pecinan desa Babagan Lasem ini serupa dengan bentukan atap dari masyarakat China yang berasal dari provinsi Fujian yaitu Notrhen China (China bagian Utara), Eastern China (China bagian Timur) dan sebagian dari Haka Region (khusus pada bagian innercourtnya saja). Tidak semua bentukan atap yang ada di provinsi Fujian dibawa ke Lasem, karena terbentuknya bangunan vernakular yang ada di Provinsi Fujian khususnya sebagian mengikuti bentukan alam. Contohnya pada loess region Yao Dong dan subterranean house yang beradaptasi mengikuti bentuk lahan dan tanah yang berbukit atau bertebing. Sedangkan permukiman yang ada di Western dan South Western serta the Southern Coast China banyak menggunakan atap jenis Hsuan Shan yaitu atap pelana dengan tiang-tiang kayu.

\section{Saran}

Sebagai saran dari hasil penelitian ini, dikarenakan ternyata bentukan atap yang ada di permukiman China desa Babagan Lasem ini serupa dengan bentukan atap yang ada di provinsi Fujian maka hal ini menjadi nilai tambah kekayaan budaya yang ada di Indonesia. Seyogyanya pemerintah 
bisa turut melestarikan permukiman ini sebagai bagian dari warisan budaya dunia. Dan untuk penelitian selanjutnya bisa mengkaji lebih dalam lagi bentukan atap dari segi struktur dan estetikanya pada permukiman China sebagai warisan budaya dunia.

\section{DAFTAR PUSTAKA}

Atlas, S. (2020). Fujian Tulou, the Hakka Walled Villages. 6 Juni 2020. https://www.sensesatlas.com/territory/fujian-tulou-the-hakka-walled-villages/

Chinasage. (2020). Traditional Chinese Architecture Jianzhu. https://www.chinasage.info/architecture.htm

Handinoto. (2008). Perkembangan Bangunan Etnis Tionghoa di Indonesia. Prosiding Simposium Nasional Arsitektur Vernakular 2, 1-17.

Jin, F. (2016). Research on the color of ancient residential architecture in Southern Fujian and its inspiration for modern urban color application. I3csee, 160-163. https://doi.org/10.2991/i3csee16.2016.31

Khol, D. G. (1984). Chinese Arcitecture in The Starits Settlements and Western Malaya: Temples Kongsis and Houses. Archipel, 33, 185.

Khudori, N. (2019). Arsitektur Atap Tradisional Tionghoa dan Filosofinya. 7 Juli. https://www.tionghoa.info/arsitektur-atap-tradisional-tionghoa-dan-filosofinya/

$\mathrm{Li}, \mathrm{X}$., \& Liu, Y. (2017). The "shape" and "meaning" of the roof arts in Chinese classical architecture. IOP Conference Series: Earth and Environmental Science, 61(1). https://doi.org/10.1088/1755$1315 / 61 / 1 / 012110$

Pratiwo, \& Nazir, S. M. (2010). Arsitektur Tradisional Tionghoa dan Perkembangan Kota. Ombak.

Rapoport, A. (1969). House Form and Culture. Prentice-hall. Englewood cliffs.

Sudarwani, M. (2012). Simbolisasi Rumah Tinggal Etnis Cina Studi Kasus Kawasan Pecinan Semarang. Jurnal Momentum UNWAHAS, 8(2), 115256.

Sudarwani, M. M., Purwanto, E., \& Rukhayah, R. S. (2019). Karakteristik Kawasan Pecinan Lasem Kabupaten Rembang. D105-D112. https://doi.org/10.32315/ti.8.d105

Zhou, N., Nishida, M., \& Kitayama, H. (2002). Study on the Thermal Environment of the YaoDong Dwelling in the Loess Plateau of China. Journal of Asian Architecture and Building Engineering, 1(1), 81-86. https://doi.org/10.3130/jaabe.1.81 